\title{
The Benthonic foraminiferal response to changing substrate in Cenomanian (Cretaceous) rhythms induced by orbitally-forced surface water productivity
}

\author{
PAUL N. LEARY \\ Department of Geological Sciences \\ University of Plymouth, \\ Drake Circus, \\ Plymouth PL4 8AA \\ Devon, U.K.
}

\author{
MALCOLM B. HART \\ Department of Geological Sciences \\ University of Plymouth, \\ Drake Circus, \\ Plymouth PL4 8AA \\ Devon, U.K.
}

\begin{abstract}
The rhythmic sedimentation of Cenomanian age in Southern England is most likely the result of orbital forcing (precession). The oxygen isotope signature and the foraminiferal assemblage from detailed $(5 \mathrm{cms})$, continuous samples through three of these rhythms show systematic variation with lithology. The marls yield cooler surface water palaeotemepratures with high benthonic diversities, low planktonic:benthonic ratios and the planktonic assemblage contains around 5-10\% rotaliporids. The chalks yield warmer surface water palaeotemperatures with low benthonic diversities, high planktonic:benthonic ratios and the planktonic assemblage contains $1-4 \%$ rotaliporids. This indicates that the chalks represent enhanced surface water productivity induced by increased surface water palaeotemperature. Three groups(Tritaxia pyramidata Reuss, Gavelinella spp. and Lenticulina spp.) together form over $90 \%$ of the benthonic assemblage. Each $>250 \mu \mathrm{m}$ assemblage exhibits a systematic variation in size with lithology. The mean sizes are smallest and the maximum sizes of the moving populations decrease in the middle of the chalks. This may be a consequence of three different factors, (a) during intervals of increased productivity (chalks) the benthonic foraminifera may be achieving gametogenesis at an enhanced rate due to the increased availability of food supplies, or (b) the increased productivity may cause dwarfism within the micro-benthos, or (c) the effects of current winnowing prior to burial. The relative merits of each of these possibilities are discussed.

J. Micropaelontol., 11 (2), 107-111 December 1992.
\end{abstract}

\section{INTRODUCTION}

In recent years the role of orbital forcing in the formation of Mesozoic rhythmic sequences has received increased attention. Most of the early investigations of these sequences have focused on the sedimentological aspects of rhythms, attempting to assess the duration of repeated units; the shale-carbonate couplets of the Blue Lias (Weedon, 1985, Hart, 1987), and the Cretaceous marl-carbonate couplets (Barron, et al., 1985; Fischer, et al., 1985; Arthur, et al., 1986, Cotillon, 1987). In the Cenomanian rhythmic sequences the lack of a reliable radiometric scheme has created great difficulty in calculating durations of individual couplets (Robinson, 1986a, b). For these UK sequences the view of House (1985) that Milankovitch scales can be used to calculate the duration of rhythmic sequences has been adopted (Gale, 1989). Adopting this approach, the most likely duration of each chalk-marl couplet is 41,000 years (precession). Using the oxygen isotope signature and foraminiferal changes through three of these couplets they have been interpreted as representing episodic enhanced surface water productivity induced by a warming in the surface waters (Ditchfield \& Marshall, 1989; Leary \& Ditchfield, in press). In this study the size variations in three taxonomic groups from the benthonic assemblage from the same sequence of marl-chalk-marl couplets are documented.

\section{LITHOSTRATIGRAPHY, SEDIMENTOLOGY AND BIOSTRATIGRAPHY}

The investigated succession is located on the coastal section between Dover and Folkestone (Southern England - Fig. 1).

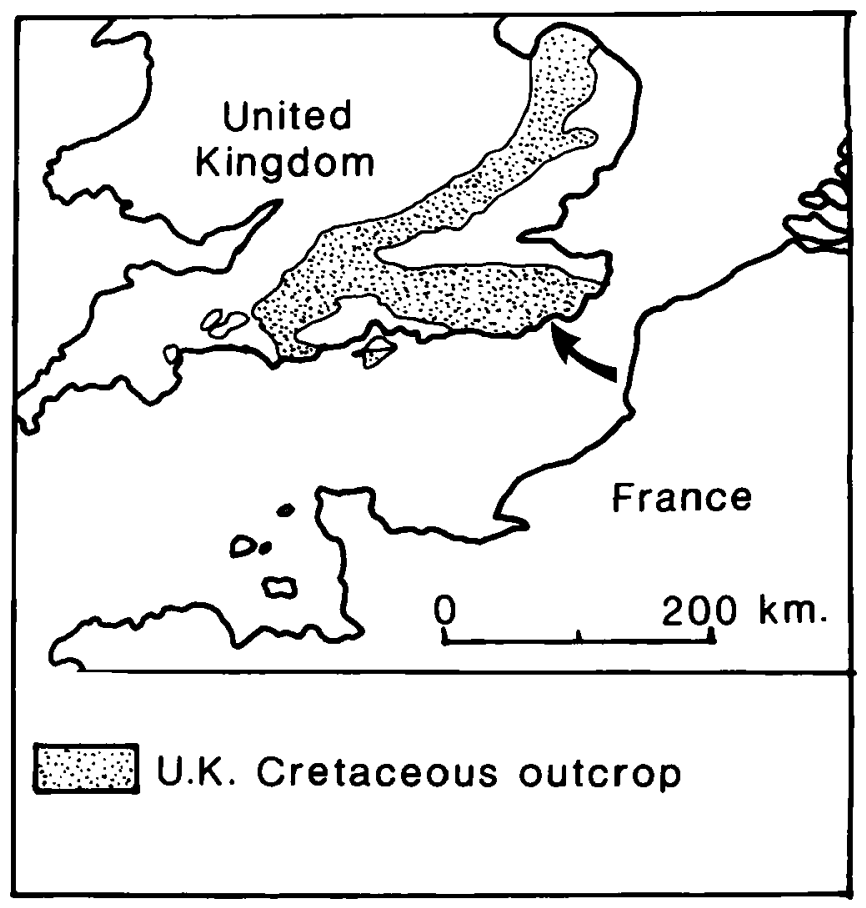

Fig.. 1. Locality map. 
The base of the investigated interval lies 5 metres from the top of the East Wear Bay Formation of Robinson (1986a). Details of the sedimentology of UK Cenomanian rhythmic sequences are available elsewhere (Kennedy, 1967; Robinson, 1968a; Ditchfield \& Marshall, 1989 op.cit.). The degree of diagenesis is low (Scholle, 1974; Ditchfield \& Marshall, op. cit.).

The presence of the planktonic foraminiferans Rotalipora cushmani (Morrow) and Rotalipora greenhornensis (Morrow) places the sequence within the internationally recognised $R$. cushmani interval zone of Robaszynski \& Caron (1979). In addition, the co-occurrence of $R$. cushmani, Plectina cenomana Carter \& Hart, Arenobulimina advena Cushman and Pseudotexturiella cretosa Cushman places the sequence within zone 11(ii) of Carter \& Hart (1977).

\section{OXYGEN ISOTOPE SIGNATURE AND PALAEOCEANOGRAPHY}

The western Anglo-Paris Basin formed part of an extensive set of marine ensialic basins connected, with full oceanic circulation, to a young, narrow North Atlantic Basin to the west. The marls and chalks have different oxygen isotope compositions which vary in a cyclical manner (Fig. 2) as a result of a repeated primary palaeotemperature shift of as much as $4.5^{\circ} \mathrm{C}$ in the surface waters. This was possibly induced by the precession of the equinoxes (Ditchfield \& Marshall, op. cit.). The chalks yield the warmer water palaeotemperatures.

\section{FORAMINIFERAL CHANGES}

Details of the changes in the planktonic and benthonic assemblages are available elsewhere (Leary \& Ditchfield, in press) but for completeness a short review is provided here. The marls (in contrast to the chalks) yield high benthonic diversities, low planktonic:benthonic ratios, and the planktonic assemblage contains a higher proportion (5-10\%) of rotaliporids (Fig. 2). The converse in the chalks has been interpreted as being the result of enhanced surface water productivity (Leary \& Ditchfield, in press). The lower benthonic assemblage from within the chalks is a result of the temporary loss (or at least reduction in abundance) of elements within the nodosarid group (Dentalina spp., Frondicularia spp. and Nodosaria spp.) and the agglutinated foraminiferid assemblage of Ataxophragmium depressum (Perner), Dorothia gradata (Berthelin), Marssonella spp., Ammodiscus cretaceous (Reuss). Eggerellina spp. and Pseudospiroplectinata plana (Gorbenko). Both of these groups constitute $0 \%-8 \%$ of the benthonic assemblage in any sample. The bulk of the benthonic assemblage $(>90 \%)$ from any sample is comprised of three groups, Lenticulina spp., Gavelinella spp. and Tritaxia pyramidata (Reuss), which were used for the morphometric study.

\section{BIOMETRIC ANALYSIS AND RESULTS}

The $>250 \mu \mathrm{m}$ fractions of Lenticulina spp., Gavelinella spp. and $T$. pyramidata populations were measured (Fig. 3) optically using a graticule. The specimens of each group were orientated and if required glued, prior to measuring to avoid spurious results. For each population two parameters were measured, either the width and height or the length and height depending on the form of the test (Fig. 3).

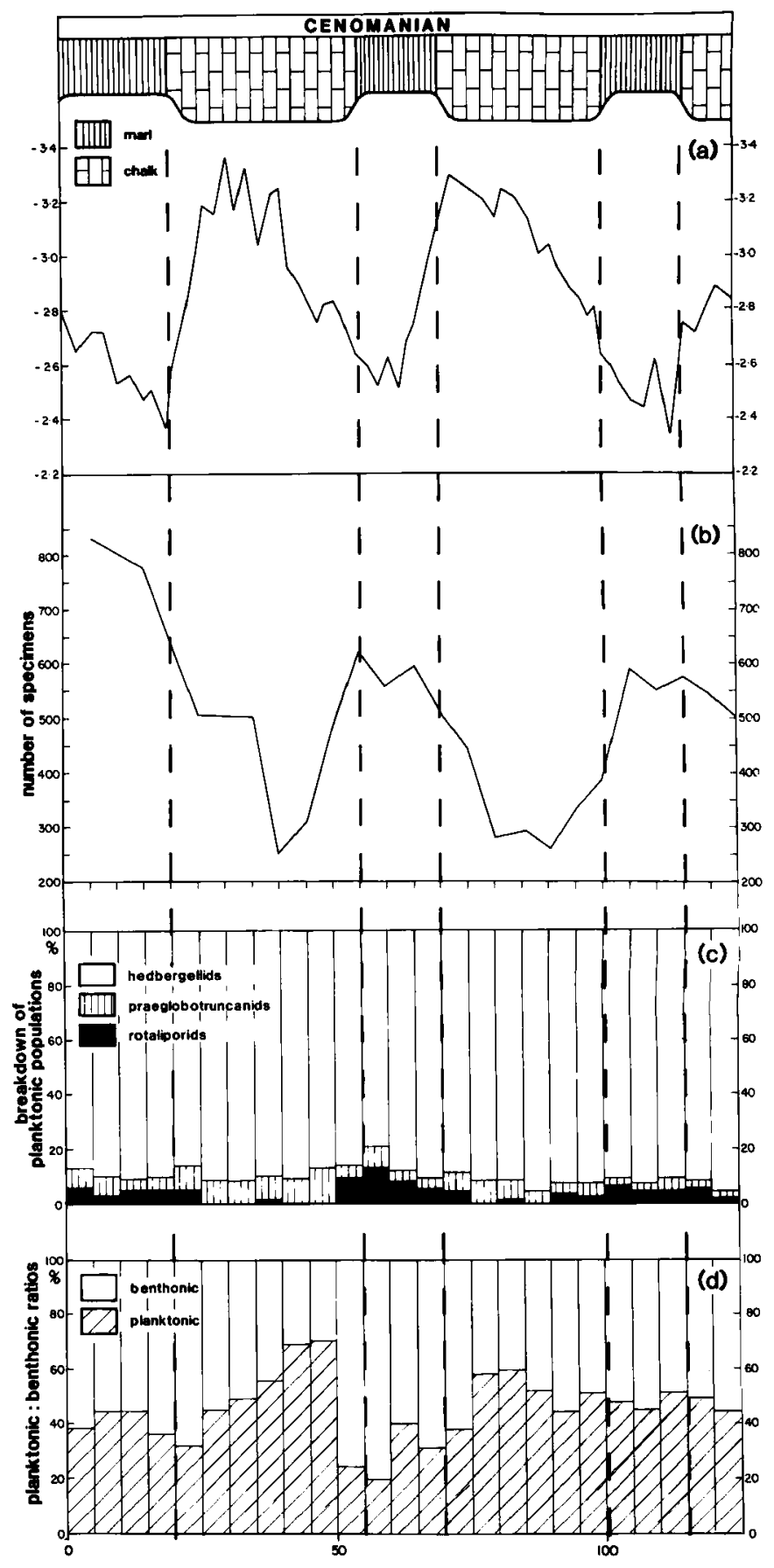

Fig. 2. Idealised sedimentological log; scale in $\mathrm{cm}$.

(a) $\partial^{18} \mathrm{O}$ signature.

(b) abundance of foraminiferans.

(c) planktonic assemblage

(d) planktonic:benthonic ratio

The plots of the mean sizes of the width (Fig. 4b) and height (Fig. 4c) of Gavellina spp. show a regular pattern with the mean sizes being slightly larger from the marl associated populations. The size histograms of these moving populations (Fig. 5b) shows that the population size structures are complex. In most 


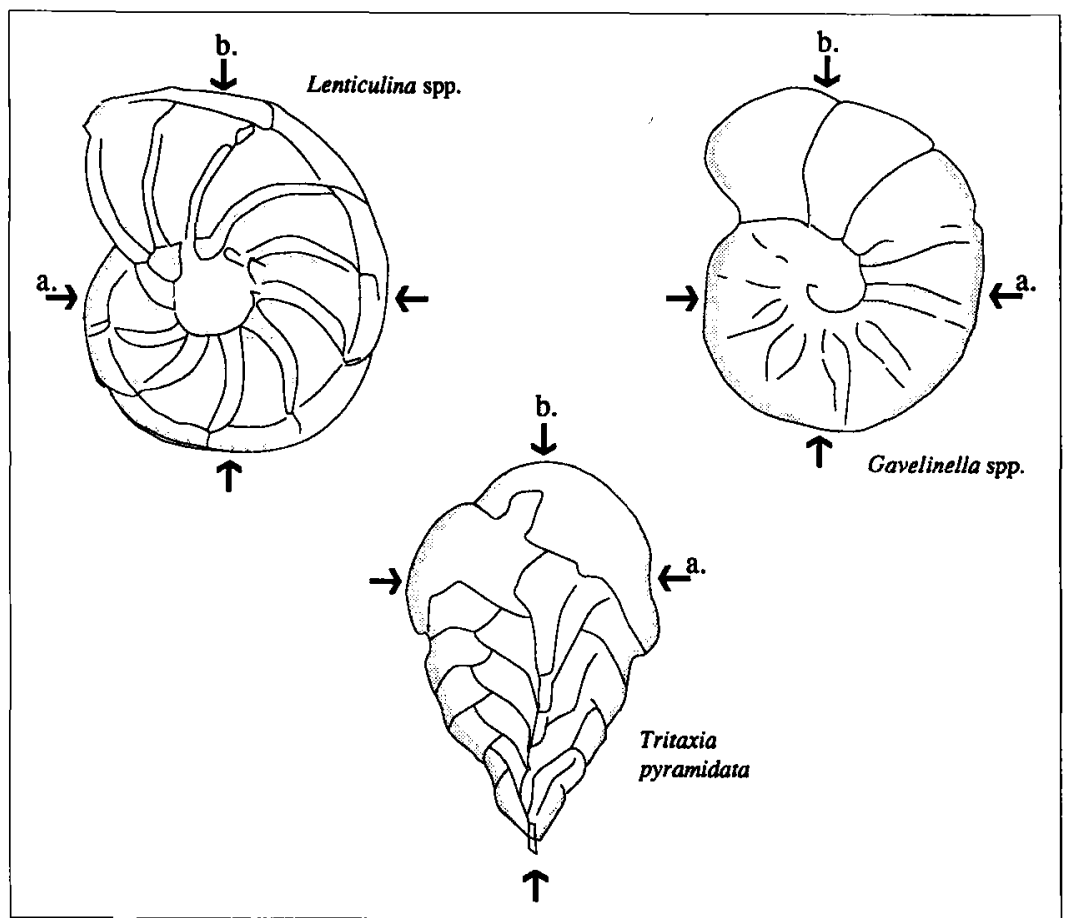

diversity changes within the micro-benthos have to be accounted for. The relative attributes of each are discussed in turn:

(a) enhanced rates of gametogenesis. At times of increased nutrient supply benthonic foraminifera pass through ontogeny at enhanced rates and thus achieve earlier gametogenesis (Murray, 1963). One of the consequences of this is that the test sizes of the gerontics tend to be smaller (Murray, op . cit.). In addition, in modern regions of the marine realm with high productivity, because of enhanced nutrient availability the diversity is often low (ref.). Thus, the high surface water productivity may have increased the flow of nutrients to the micro-benthos leading to the observed combination of smaller test size and low species diversity.

(b) dwarfism. Within many extant and fossil groups dwarfism has been noted as a response to adverse conditions. All three groups most likely had an epifaunal or semi-infaunal mode of existence for most of their ontogeny (see

Fig. 3. Dimensions (a-a and b-b) measured on Tritaxaia pyramidata Reuss, Gavelinella spp. and Lenticulina spp.

cases, the populations are positive skewed (except the 10-15, 20-25 and 50-55 samples) indicating the presence of more juveniles than gerontics. In additon the populations with the smallest maximum sizes are from the middle of the chalks.

The plots of the mean sizes of the width (Fig. 4d) and height (Fig. 4e) of Lenticulina spp. show a regular pattern with the mean sizes being larger from the marl associated populations. The size histograms of these moving populations (Fig. $5 \mathrm{c}$ ) are less steep than those recorded from the Gavelinella spp. populations, indicating a more balanced distribution in the numbers of juveniles and gerontics. They show that the maximum sizes of the populations also decrease within the middle of the chalks (Fig. 5c).

The plots of the mean sizes of the width (Fig. 4f) and height (Fig. $4 \mathrm{~g}$ ) of $T$. pyramidata show a semi-regular pattern with the mean sizes being larger from the marl associated populations. The size histograms of these moving populations (Fig. 5a) are complex, but generally they are steep, indicating much higher numbers of juveniles than gerontics within each population. The maximum sizes of the population decrease within the middle of the chalks, although the populations from the second marl do not show such large population sizes as those from the other two marls. (Fig. 5a).

\section{INTERPRETATION}

There are three possible explanations for these size variations and in the bulk of the benthonic assemblage through the rhythms (enhanced rates of gametogenesis, dwarfism and current winnowing). These influences and processes are not totally mutually exclusive as current winnowing could easily overprint any palaeobiological influence. In addition the
Koutsoukos \& Hart, 1990, for a recent review of the life habits of Cenomanian benthonic foraminifera). The chalks most likely represent episodes of enhanced surface water carbonate production superimposed on the steady "clay rain" of the marls (Ditchfield \& Marshall, op. cit.). This increased sedimentation rate could haveadversely affected the benthonic foraminifera and caused dwarfism, although the case for dwarfism within the benthonic foraminifera is not proven (Murray, pers. comm.). If this enhanced carbonate sedimentation rate was adverse for the benthonic foraminifera it could also account for the accompanying drop in benthonic foraminiferal diversity.

(c) current winnowing. Many sedimentary depositional processes effectively size fractionate sediment (see Reading, 1986). The movement and size fractionation of foraminiferal tests on the sea floor prior to burial has been noted (Simien, 1987; Robaszynski, 1988). Comparison of the three histograms of the size distribuitions of the T. pyramidata, Gavellinella spp. and Lenticulina spp. populations (Fig. 4) shows that the magnitude of the size changes within each population is not the same, which indicates that current winnowing is not the cause.

\section{CONCLUSIONS}

The benthonic foraminifera through three Cenomanian rhythms show consistent patterns. The maximum test sizes of three groups decreases and the diversity drops within the middle of the chalks. This could be the result of two possible influences; enhanced rates of gametogenesis during episodes of increased nutrient available or dwarfism through adverse conditions brought about by enhanced carbonate sedimentation rates. Further studies are required to distinguish between the two. 


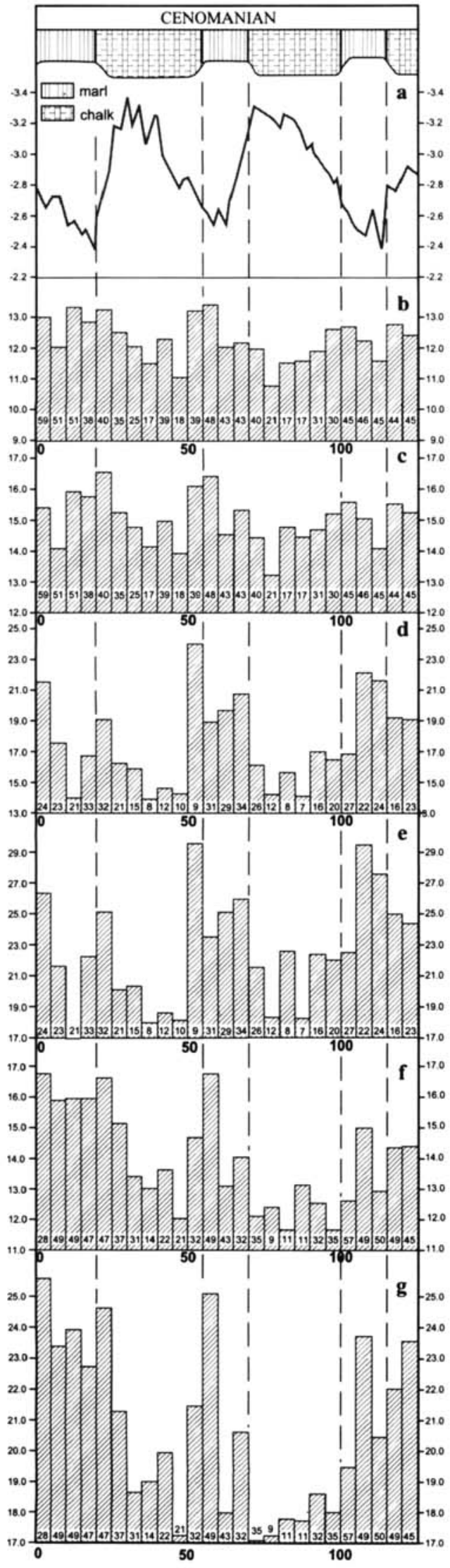

\section{ACKNOWLEDGEMENTS}

The samples were kindly provided by Peter Ditchfield (Liverpool) and the oxygen isotopes were run by the Isotope Unit (Liverpool) under the guidance of Jim Marshall. The author is grateful to Polytechnic South West for theopportunity provided by a three year fellowship. Special thanks are offered to John Abraham and Sharon Braley for their diligent diagram drawing. Finally, the thoughtful comments of Danny Dahmer (Berlin) on the relevance of size variations within extant benthonic foraminifera are gratefully acknowledged. Marylyn Luscott-Evans is thanked for final preparation of the manuscript.

\section{Manuscript received May 1991 \\ Manuscript accepted August 1992}

\section{REFERENCES}

Arthur, M.A., Bottjer, D.J., Dean, W.E., Fischer, A.G., Hattin, D.E., Dauffman, E.G., Pratt, L.M. \& Scholle, P.A. 1986. Rhythmic bedding in Upper Cretaceous pelagic carbonate sequences: varying sedimentary response to climatic forcing. Geology, 14, 153-156.

Barron, E.J., Arthur, M.A. \& Kauffman, E.G. 1985. Cretaceous rhythmic bedding sequences: a plausible link between orbital variations and climate. Earth and Planetary Science Letters, 72, 327-340.

Carter, D.J. \& Hart, M.B. 1977. Aspects of mid-Cretaceous stratigraphical micropalaeontology. Bulletin of the British Muesum, Natural History (Geology), 29, 1-135.

Cotillon, P. 1987. Bed-scale cyclicity of pelagic Cretaceous successions as a result of world-wide control. Marine Geology, 78, 109-123.

Ditchfield, P. \& Marshall, J. 1989. Isotopic variations in rhythmically bedded chalks; palaeotemperature variation in the Upper Cretaceous. Geology, 17, 842-845.

Fischer, A.G., Herbert, T. \& Premoli-Silva. 1985. Carbonate bedding cycles in Cretaceous pelagic and hemipelagic sequences. In: Fine grained deposits and biofacies of the Cretaceous western interior seaway: evidence of cyclic sedimentary processes. (Eds L.M. Pratt, Kauffman, E.G. \& Zelt, F.B.), Society of Economic Paleontologists and Mineralogists, Field Trip guide Book, No.4, 1-10.

Gale, A.S. 1989. A Milankovitch scale for Cenomanian time. Terra Nova, 1, 420-425.

Hart, M.B. 1987. Orbitally induced cycles in the Mesozoic sediments of SW England. Proceedings of the Ussher Society, 6, 483-490.

Herbert, T.D. \& Fischer, A.G. 1986. Milankovitch climatic origin of mid-Cretaceous black shale rhythms in central Italy. Nature, 321, 739-743.

House, M.R. 1985. A new approach to an absolute timescale from the measurement of cycles and sedimentary microrhythms. Nature, 315, 721-725.

Kennedy, W.J. 1967. Field meeting at Eastbourne, Sussex. Lower Chalk sedimentation. Proceedings of the Geologists' Association, 77, 365-370.

Koutsoukos, E.A.M. \& Hart, M.B. 1990. Cretaceous foraminiferal morphogroup distribution patterns, palaeocommunities and trophic structures: a case study from the Sergipe Basin, Brazil. Transactions of the Royal Society of Edinburgh: Earth Sciences, 81, 221-246.

Fig. 4. Mean sizes of Gavelinella spp., Lenticulina spp. and Tritaxia pyramidata (Reuss) populations.

(a) $\partial^{18} \mathrm{O}$ signature.

(b) mean width (a) of Gavelinella spp.,population.

(c) mean height (b) of Gavelinella spp. population.

(d) mean width (a) of Lenticulina spp. population.

(e) mean height (b) of Lenticulina spp. population.

(f) mean width (a) of Tritaxia pyramidata population

(g) mean height (b) of Tritaxia pyramidata population 
Koutsoukos, E.A.M., Leary, P.N. \& Hart, M.B. 1990. Latest Cenomanian-Earliest Turonian low-oxygen tolerant benthonic Foraminifera: a case study from the Sergipe Basin (NE Brazil) and the western Anglo-Paris Basin (Southern England). Palaeogeography, Palaeoclimatology, Palaeoecology, 77, 145-177.

Leary, P.N. \& Ditchfield, P., in press. The foraminiferal assemblage against the oxygen isotope signature through three Cenomanian (Cretaceous) marl chalk-marl rhythms from SE England. Mesozoic Research.

Muray, J.W. 1963. Ecological experiments on Foraminiferida. Journal of the Marine Biological Association of the UK, 43,621642.

Reading, H.G. (Ed.) 1986. Sedimentary Environments and Facies (2nd Edition), Blackwell Scientific Publications, Oxford, U.K., 615pp.

Robaszynski, F. 1988. Upper Cretaceous planktonic foraminifera from Northern Belgium and the southeastern Netherlands. In: The Chalk District of the Euregio MeuseRhine (eds. M. Streel \& Bless, M.J.M.), 77-83.

Robaszynski, F. \& Caron, M. 1979. Atlas of Mid-Cretaceous planktonic Foraminiferida (Boreal Sea and Tethys). Cahiers de Micropaleontologie, Part 1, 1-185; Part 2, 1-181 (in English and French).

Robinson, N.D. 1986a. Lithostratigraphy of the Chalk Group of the North Downs, southeast England. Proceedings of the Geologists' Association, 97(2), 141-170.

Robinson, N.D. 1986b. Fining-upward microrhythms with basal scours in the Chalk of Kent and Surrey, England and their stratigraphic significance. Newsletters on Stratigraphy, $17,21-28$.

Scholle, P.A. 1974. Diagenesis of Upper Cretaceous Chalk from England, Northern Ireland. Special Publications of the International Association of Sedimentologists, 1, 117-210.

Simien, T.R.1987. From coastal terrigineous deposits to pelagic rich oozes: the Holocene transgressive complex of southern Belize lagoon (C.A.). A tool for the past? Abstract No.13. In: Comparative sedimentology Laboratory, University of Miami, Rosensteil School of Marine and Atmospheric Sciences, Miami, 32-35.

Weedon, G.P. 1985. Hemipelagic shelf sedimentation and climatic cycles: the basal Jurassic (Blue Lias) of South Britain. Earth \& Planetary Letters, 76, 321-335.

Fig. 5. Histograms of size distributions of each population, from $5 \mathrm{~cm}$ thick samples,

(a) Tritaxia pyramidata Reuss.

(b) Gavelinella spp. population.

(c) Lenticulina spp. population.

The numbers in each column refer to the number of specimens measured.

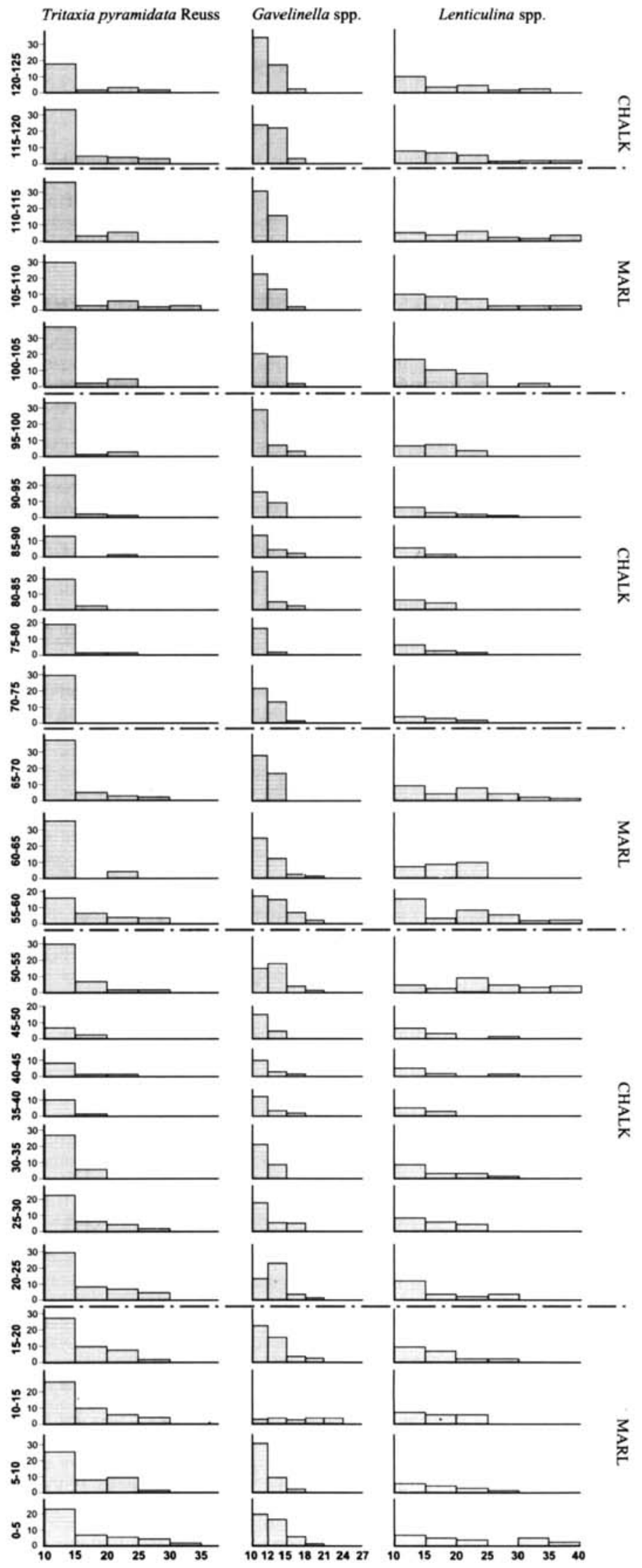

